\title{
Statyba
}

\section{ENERGY INTERPRETATION OF COMPLEMENTARITY CONDITIONS IN SHAKEDOWN PROBLEMS}

\section{J. Atkočiūnas}

To cite this article: J. Atkočiūnas (1997) ENERGY INTERPRETATION OF

COMPLEMENTARITY CONDITIONS IN SHAKEDOWN PROBLEMS, Statyba, 3:9, 14-25, DOI:

10.1080/13921525.1997.10531667

To link to this article: https://doi.org/10.1080/13921525.1997.10531667

曲 Published online: 26 Jul 2012.

Submit your article to this journal $\pi$

III Article views: 38 


\section{ENERGY INTERPRETATION OF COMPLEMENTARITY CONDITIONS IN SHAKEDOWN PROBLEMS}

\section{J. Atkočiūnas}

\section{Introduction}

A progress in computing technology has presented a new means in structural mechanics to determine the stress and strain field (SSF) of elasticplastic structures. One of relatively new methods is the one, based on the use of the extremum energy principles of deformable solid mechanics in formulating the SSF problems by applying the dual mathematical programming theory [1]-[6]. Mechanical interpretation of the main conditionsconstraints of mathematical models there plays the basic role. First of all, this is related to the complementarity conditions (also known as additional orthogonality conditions), which cannot directly fix the possible unloading, the most often met when considering the affect of cyclic loading (CL) [7][9]. The stress-strain field of a dissipative structure in general is related to the history of loading. Various aspects of the SSF of shakedown structures are considered in [10]-[19] and some other works. Special energetic interpretation of the above - mentioned complementarity conditions ensures a more exact determination of residual stresses and strains for elastic-plastic structures (the SSF analysis problem).

\section{Definitions and relationships of a discrete structural model}

An elastic perfectly plastic structure is considered, the physical and geometric characteristics are assumed to be known. Considerations confirm the validity of the small displacement approach. The discrete model of the structure is obtained by dividing it into $\zeta$ finite elements, the total number of design cross-sections being $s$ (the set of their indices is I).The cross-sections are assumed to be of an ideal form. It is convenient to split the displacements u, stresses S and strains $\Theta$ into "elastic" and "residual" parts. The number of the components of all stress vectors $\mathbf{S}=\mathbf{S}_{e}+\mathbf{S}_{r}$ and that of the strains $\Theta=\Theta_{e}+\Theta_{r}$ is equal to $n$ (the subscript $e$ refers to the vectors obtained from the elastic design; additional terms follow from the presence due to plastic strains $\Theta_{p}$ ). The degree of freedom in the discrete model of the structure is $m$. The cyclic loading is defined by the variation bounds $\mathbf{F}_{\text {inf }} \leq \mathbf{F}(t) \leq \mathbf{F}_{\text {sup }}$, which are known and not related to the time $t$. The structure is supposed to be in a state of shakedown. The simple loading $F$ is considered a particular case of the cyclic loading: $\mathbf{F}=\mathbf{F}_{\text {inf }}=\mathbf{F}_{\text {sup }}$. The equilibrium equations read

$$
[A] \mathbf{S}=\mathbf{F} .
$$

Here $[A]$ is a $(m \times n)$ matrix of the coefficients of the equilibrium equations. $[A]^{T}$ is the matrix of compatibility depending on the geometry of the structure. The statically possible vector $\mathbf{S}$ from equilibrium equations (1)

$$
\left[A^{\prime}\right] \mathbf{S}^{\prime}+\left[A^{\prime \prime}\right] \mathbf{S}^{\prime \prime}=\mathbf{F}
$$

is obtained via the following relationship:

$$
\mathbf{S}=\left[A_{p}\right]^{-1} \mathbf{F}+\left[A_{p}^{0}\right] \mathbf{S}^{\prime \prime} \text {. }
$$

Here the matrices $\left[A_{p}\right]^{-1},\left[A_{p}^{0}\right] \mathrm{read}$

$$
\begin{gathered}
\left(\left[A_{p}\right]^{-1}\right)^{T}=\left[\left(\left[A^{\prime}\right]^{-1}\right)^{T},[0]\right], \\
{\left[A_{p}^{0}\right]^{T}=\left[-\left[A^{\prime \prime}\right]^{T}\left(\left[A^{\prime}\right]^{-1}\right)^{T},[I]\right],}
\end{gathered}
$$

respectively. The equalities 


$$
\begin{gathered}
{[A]\left(\left[A_{p}\right]^{-1} \mathbf{F}+\left[A_{p}^{0}\right] \mathbf{S}^{\prime \prime}\right)=\mathbf{F},} \\
{[A]\left[A_{p}^{0}\right] \mathbf{S}^{\prime \prime}=\mathbf{0},}
\end{gathered}
$$

by using the expression

$$
[A]\left[A_{p}^{0}\right]=[0] \text { and }\left[A_{p}^{0}\right]^{T}[A]^{T} \mathbf{u}=\mathbf{0},
$$

lead to the compatibility equations of strains

$$
\left[A_{p}^{0}\right]^{T} \Theta=\mathbf{0} .
$$

The matrix $-\left[A_{p}^{0}\right]^{T}$ in actual article is denoted by $[B]=-\left[A_{p}^{0}\right]^{T}$. Then it is easy to find that the elastic stresses $\mathbf{S}_{e}$, applying the force method relationships $\left[\beta_{q}\right] \mathbf{S}_{e}^{\prime \prime}+\left[\beta_{p}\right] \mathbf{F}=\mathbf{0}$, read

$$
\mathbf{S}_{e}=[\alpha] \mathbf{F}=\left(\left[A_{p}\right]^{-1}-\left[A_{p}^{0}\right]\left[\beta_{q}\right]^{-1}\left[\beta_{p}\right]\right) \mathbf{F} .
$$

Here $[\alpha]$ is the influence matrix for elastic stresses, the matrices $\left[\beta_{q}\right],\left[\beta_{p}\right]$ are denoted as

$$
\left[\beta_{q}\right]=\left[A_{p}^{0}\right]^{T}[D]\left[A_{p}^{0}\right], \quad\left[\beta_{p}\right]=\left[A_{p}^{0}\right]^{T}[D]\left[A_{p}\right]^{-1}
$$

respectively. Here the quantity $[D]$ is the diagonal flexibility matrix of the elements of the structure. Under cyclic loading the vectors $\mathbf{S}_{e j, \text { min }}, \mathbf{S}_{e j, \text { max }}$ define all apexes of the hodograph of the elastic forces:

$$
\mathbf{S}_{e}(t)=[\alpha] \mathbf{F}(t), \quad \mathbf{F}_{\text {inf }} \leq \mathbf{F}(t) \leq \mathbf{F}_{\text {sup }} .
$$

The subscript $j$ denotes their symmetric pair, their set is $J(j \in J)$; the set of the indices of all is denoted by $P, p \in P$. The extreme elastic stresses $\mathbf{S}_{e j \text { min }}, \mathbf{S}_{e j, \max }$ are the linear functions of the prescribed bounds $\mathbf{F}_{\text {inf }}, \mathbf{F}_{\text {sup }}$.

The linear yield conditions

$$
[\Phi]\left(\mathbf{S}_{e}(t)+\mathbf{S}_{r}(t)\right) \leq \mathbf{S}_{0}
$$

are verified in the cross-sections or in the apriori prescribed points of the discrete model of the structure. Here $\mathbf{S}_{0}$ is the prescribed vector of limit stresses of the discrete model of the structure. The condition (7) is the result of the requirement stating that the total stresses $\mathbf{S}$ must remain inside the admissible domain. The matrix [Ф] contains the unit vectors perpendicular to the plane facets of domain (7). Solving the shakedown problems, all apexes of the hodograph $\mathbf{S}_{e}(t)$ are simultaneously taken into account in the linear yield conditions (7):

$[\Phi]\left(\mathbf{S}_{e j \text { max }}+\mathbf{S}_{r}\right) \leq \mathbf{S}_{0}, \quad[\Phi]\left(\mathbf{S}_{e j \text { min }}+\mathbf{S}_{r}\right) \leq \mathbf{S}_{0}$ for all values of $j \in J$.

Here $\mathbf{S}_{r}$ is the any time-independent residual stress vector (it, in general, depends on the loading history) [20]. The statically admissible vector $\mathbf{S}_{r}$ satisfies the equilibrium equations (1) and the yield conditions (8). It is known that such a vector satisfies the conditions of the static Melan principle for shakedown state of the structure [21]. Application of the mathematical programming theory yields that a solution for extremum problem of shakedown exists. For simple loading $\mathbf{F}=\mathbf{F}_{\text {inf }}=\mathbf{F}_{\text {sup }}$. Then the yield conditions are

$$
[\Phi]\left(\mathbf{S}_{e}+\mathbf{S}_{r}\right) \leq \mathbf{S}_{0} .
$$

The plastic flow rule associated with the yield conditions (7) reads

$$
\dot{\Theta}_{p}(t)=[\Phi]^{T} \dot{\lambda}(t),
$$

$$
\begin{gathered}
\dot{\lambda}(t) \geq 0, \text { if } \mathbf{S}_{0}-[\Phi]\left(\mathbf{S}_{e}(t)+\mathbf{S}_{r}(t)\right)=\mathbf{0}, \\
\dot{\lambda}(t)=\mathbf{0}, \text { if } \mathbf{S}_{0}-[\Phi]\left(\mathbf{S}_{e}(t)+\mathbf{S}_{r}(t)\right)>\mathbf{0} .
\end{gathered}
$$

Here $\dot{\lambda}(t)$ is a vector of intensities of plastic flow. For a given instant $\tau$

$$
\Theta_{p}=\int_{0}^{\tau} \dot{\Theta}_{p}(t) d t=[\Phi]^{T} \lambda, \text { with } \lambda=\int_{0}^{\tau} \dot{\lambda}(t) d t
$$

Under the assumption of small displacements the geometric relation is linear:

$$
[A]^{T} \mathbf{u}=\Theta
$$

here $\mathbf{u}=\mathbf{u}_{e}+\mathbf{u}_{r}, \quad \Theta=\Theta_{e}+\Theta_{r} . \quad$ The vector $\Theta_{r}$ denotes the residual strains

$$
\Theta_{r}=[D] \mathbf{S}_{r}+\Theta_{p}
$$

Then

$$
[A]^{T} \mathbf{u}_{e}=\Theta_{e} \text { and }[A]^{T} \mathbf{u}_{r}=\Theta_{r} .
$$


Kinematically admissible residual displacements $\mathbf{u}_{r}$ satisfy relationships

$$
[D] \mathbf{S}_{r}+[\Phi]^{T} \lambda-[A]^{T} \mathbf{u}_{r}=\mathbf{0}, \lambda \geq \mathbf{0} .
$$

Here the vector $\lambda$ satisfies the formulae:

$$
\begin{gathered}
\lambda=\sum_{j}\left(\lambda_{j, \max }+\lambda_{j, \min }\right), \\
\lambda_{j, \min } \geq \mathbf{0}, \lambda_{j, \max } \geq \mathbf{0}, \\
\lambda_{j, \min }^{T}\left[\mathbf{S}_{0}-[\Phi]\left(\mathbf{S}_{e j, \min }+\mathbf{S}_{r}\right)\right]=0, \\
\lambda_{j, \max }^{T}\left[\mathbf{S}_{0}-[\Phi]\left(\mathbf{S}_{e j, \max }+\mathbf{S}_{r}\right)\right]=0 ; j \in J
\end{gathered}
$$

Expressions (10), (15) in mathematical programming theory are known as complementarity conditions [22], [23]. The conditions (15) do not allow via $\lambda$ to fix the appeared plastic flow during the actual process of deformation, for instance, before reaching the state of shakedown.

\section{Extremum analysis problem of holonomic structures}

\subsection{Energy concepts}

The SSF of dissipative structure depends on the loading history. For simple loading assumption of unloading naturally is not in question. Under this assumption the SSF determination problem can be realized by the direct solution of the dual mathematical programming problem, introducing the final magnitude of $\mathbf{F}$ (the effect of monotonically increasing load from zero up to its final magnitude is not required to evaluate). Aforementioned mathematical programming problems are formulated on the basis of the extremum energy principles, namely minimum complementary energy and that of the minimum total potential energy principles [4]. Another energy concepts are also introduced. An irreversible work of external loads $\mathbf{F}$ reads

$$
W=W(\tau)=\int_{0}^{\tau} \mathbf{F}^{T}(t) \dot{\mathbf{u}}_{r}(t) d t=\mathbf{F}^{T} \mathbf{u}_{r}
$$

and direct work of plastic strains $\Theta_{p}$ is

$$
D_{e}=D_{e}(\tau)=\int_{0}^{\tau} \mathbf{S}_{e}{ }^{T}(t) \cdot \dot{\Theta}_{p}(t) d t=\mathbf{S}_{e}^{T} \Theta_{p}
$$

$$
W=D_{e}
$$

The total plastic energy dissipation $D$ can be expressed by a sum of energy dissipation of residual stresses

$$
D_{r}=D_{r}(\tau)=\int_{0}^{\tau} \mathbf{S}_{r}^{T}(t) \cdot \dot{\Theta}_{p}(t) d t=\mathbf{S}_{r}^{T} \Theta_{p}
$$

and that of direct work of plastic strains $D_{e}$ :

$$
D=D_{r}+D_{e} \quad \text { or } \quad D=D_{r}+W .
$$

\subsection{Dual mathematical models of the analysis problem}

The actual field of residual stresses preceding the plastic failure can be obtained by using the extreme principle of the minimum complementary energy (the static formulation of the SSF analysis problem):

find

$$
\min \mathscr{H}^{\prime}\left(\mathbf{S}_{r}\right)=\min \quad 0.5 \cdot \mathbf{S}_{r}^{T}[D] \mathbf{S}_{r}=U^{*}
$$

subject to

$$
[A] \mathbf{S}_{r}=\mathbf{0}, \quad[\Phi]\left(\mathbf{S}_{e}+\mathbf{S}_{r}\right) \leq \mathbf{S}_{0}
$$

Here $\mathbf{S}_{e}=[\alpha] \mathbf{F}$. By solving the problem (21)-(22) the vector $\mathbf{S}_{r}^{*}$ and the minimum value of the complementary energy $U^{*}$ are determined. The problem (21)-(22) solution $\mathbf{S}_{r}^{*}$ is unique due to the positive definability of the matrix $[D]$ and the convexity of yield conditions (22).

The Kuhn-Tucker conditions related to minimization problem (21)-(22) read [22], [23]

$$
\begin{aligned}
& \nabla \mathscr{F}^{\prime}\left(\mathbf{S}_{r}^{*}\right)+[\Phi]^{T} \lambda-[A]^{T} \mathbf{u}_{r}=\mathbf{0}, \\
& \lambda \geq \mathbf{0}, \quad \lambda^{T}\left[\mathbf{S}_{0}-[\Phi]\left(\mathbf{S}_{e}+\mathbf{S}_{r}^{*}\right)\right]=0 .
\end{aligned}
$$

Here $\nabla f^{\prime}\left(\mathbf{S}_{r}^{*}\right)$ is the gradient of objective function ${ }^{\prime}\left(\mathbf{S}_{r}\right)$. The Kuhn-Tucker conditions (23) are known as compatibility equations of residual strains of elastic-plastic structure [23], [24]:

$$
\begin{gathered}
{\left[B_{\lambda}\right] \lambda=\left[B_{r}\right] \mathbf{S}_{r}^{*},} \\
\lambda \geq \mathbf{0}, \quad \lambda^{T}\left[\mathbf{S}_{0}-[\Phi]\left(\mathbf{S}_{e}+\mathbf{S}_{r}^{*}\right)\right]=0 .
\end{gathered}
$$


The order of the matrix $\left[B_{\lambda}\right]=[B][\Phi]^{T}$ is $(k \times s)$, where $k=n-m$ and

$$
\begin{aligned}
& {[B]=\left[\left[A^{\prime \prime}\right]^{T}\left(\left[A^{\prime}\right]^{T}\right)^{-1},-[I]\right] \quad \text { and }} \\
& {\left[B_{r}\right]=-\left[A^{\prime \prime}\right]^{T}\left(\left[A^{\prime}\right]^{T}\right)^{-1}\left[D^{\prime}\right]+\left[D^{\prime \prime}\right]}
\end{aligned}
$$

The compatibility equations (24)-(25) can be obtained by direct use of the formula (4).

The kinematical formulation of the SSF analysis problem reads

find

$$
\begin{aligned}
\min & \left\{0.5 \cdot \mathbf{S}_{r}^{T}[D] \mathbf{S}_{r}+\lambda^{T}[\Phi] \mathbf{S}_{r}+\right. \\
& \left.+\lambda^{T}\left[\mathbf{S}_{0}-[\Phi]\left(\mathbf{S}_{e}+\mathbf{S}_{r}\right)\right]\right\}=\Pi^{*}
\end{aligned}
$$

subject to

$$
[D] \mathbf{S}_{r}+[\Phi]^{T} \lambda-[A]^{T} \mathbf{u}_{r}=\mathbf{0}, \quad \lambda \geq \mathbf{0}
$$

The problem (26)-(27) corresponds to the principle of the minimum total potential energy $\Pi$. By solving the problem (26)-(27), the vectors $\mathbf{s}_{r}^{*}, \mathbf{u}_{r}^{*}, \lambda^{*}$ are determined. Changing the sign of the objective function (26) the problem, dual to that of (21)-(22) is obtained:

find

$$
\begin{aligned}
\max \mathscr{F}^{\prime \prime} & \left(\mathbf{S}_{r}, \mathbf{u}_{r}, \lambda\right)=\max \left\{-0.5 \cdot \mathbf{S}_{r}^{T}[D] \mathbf{S}_{r}-\right. \\
& \left.-\lambda^{T}[\Phi] \mathbf{S}_{r}-\lambda^{T}\left[\mathbf{S}_{0}-[\Phi]\left(\mathbf{S}_{e}+\mathbf{S}_{r}\right)\right]\right\}
\end{aligned}
$$

subject to

$$
[D] \mathbf{S}_{r}+[\Phi]^{T} \lambda-[A]^{T} \mathbf{u}_{r}=\mathbf{0}, \lambda \geq \mathbf{0}
$$

\subsection{Energy interpretation of duality theorems}

The first item of objective function (28) means the complementary energy $U_{r}=0.5 \cdot \mathbf{S}_{r}^{T}[D] \mathbf{S}_{r}$, the second one, according to the formula (19), means the energy dissipation of residual stresses $D_{r}=\Theta_{p}^{T} \mathbf{S}_{r}$ [4]:

$$
D_{r}=\Theta_{p}^{T} \mathbf{S}_{r}=\lambda^{T}[\Phi] \mathbf{S}_{r}
$$

According to the first duality theorem for solution of the problems (21)-(22) and (28)-(29), the objective functions are equal:

$$
0.5 \cdot \mathbf{S}_{r}^{* T}[D] \mathbf{S}_{r}^{*}=-0.5 \cdot \mathbf{S}_{r}^{* T}[D] \mathbf{S}_{r}^{*}-\lambda^{* T}[\Phi] \mathbf{S}_{r}^{*}
$$

Here the expression for the energy dissipation $D_{r}$ reads

$$
D_{r}=-\mathbf{S}_{r}^{* T}[D] \mathbf{S}_{r}^{*}=-2 U_{r}^{*}
$$

The relations (31) mean that the elastic potential of the residual stresses is equal to the complementary work.

The equations (32) can be also obtained by multiplying the geometric equations (29) to $\mathbf{S}_{r}^{*}$, taking into account that $\mathbf{S}_{r}^{*}[A]^{T} \mathbf{u}_{r}^{*}=0$.

On the other hand, geometric equations (29)

$$
[A]^{T} \mathbf{u}_{r}^{*}=[D] \mathbf{S}_{r}^{*}+[\Phi]^{T} \lambda^{*}
$$

multiplying by the vector $\mathbf{S}_{e}\left(\mathbf{S}_{e}=[\alpha] \mathbf{F}\right)$ we have [23]:

$$
\begin{gathered}
\mathbf{S}_{e}^{T}[A]^{T} \mathbf{u}_{r}^{*}=\mathbf{S}_{e}^{T}[D] \mathbf{S}_{r}^{*}+\mathbf{S}_{e}^{T}[\Phi]^{T} \lambda^{*}, \\
\mathbf{S}_{e}^{T}[A]^{T}=\mathbf{F}^{T}, \quad \mathbf{S}_{e}^{T}[D] \mathbf{S}_{r}^{*}=0
\end{gathered}
$$

Finally, it leads to the known equality (18).

The second theorem of duality of mathematical programming for optimal solution $\mathbf{s}_{r}^{*}, \mathbf{u}_{r}^{*}, \lambda^{*}$ reads:

$$
\lambda^{* T}\left[\mathbf{S}_{0}-[\Phi]\left(\mathbf{S}_{e}+\mathbf{S}_{r}^{*}\right)\right]=0
$$

Conditions (33) for $\lambda^{*}, \mathbf{s}_{r}^{*}, \mathbf{s}_{e}$ further will be denoted as the global complementarity conditions (the local complementarity conditions are actual in step-by-step analysis of the SSF). Further we consider conditions

$$
\lambda^{* T} \mathbf{S}_{0}-\lambda^{* T}[\Phi] \mathbf{S}_{r}^{*}-\lambda^{* T}[\Phi] \mathbf{S}_{e}=0
$$

taking into account the formula (32). Analysing the first item in (34), it is obvious that it means the total energy dissipation

$$
D=\lambda^{* T} \mathbf{S}_{0}
$$

One can see that for the separate components $\lambda_{i^{-}, \mu}^{*}=0$ relations

$$
[\Phi]_{i{ }^{-}, \mu}\left(\mathbf{S}_{e i}+\mathbf{S}_{n i}^{*}\right)<\mathbf{S}_{0 i^{-}, \mu}, i^{-} \in I,
$$


are valid; and for the components $\lambda_{i^{+}, \mu}^{*} \geq 0$ equalities

$$
[\Phi]_{i^{+}, \mu}\left(\mathbf{S}_{e i}+\mathbf{S}_{r i}^{*}\right)=\mathbf{S}_{0 i^{+}, \mu} i^{+} \in I .
$$

are also valid. Here $\mu$ is the number of the plane face of domain (7) (the number of lines of the linear yield conditions matrix $[\Phi]_{i}$ ). In degenerate analysis problem it is possible the case when $\lambda_{i^{+}, \mu}=0$ and $[\Phi]_{i^{+}, \mu}\left(\mathbf{S}_{e i}+\mathbf{S}_{n i}^{*}\right)=\mathbf{S}_{0 i^{+}, \mu}$. Finally, equation

leads to the known expression (20):

$$
D=-\mathbf{S}_{r}^{* T}[D] \mathbf{S}_{r}^{*}+\lambda^{*^{T}}[\Phi] \mathbf{S}_{e} .
$$

\subsection{The complete set of constraints of elastic-plastic structure}

The complete set of the equations (the generalized Lagrange problem of elastic-plastic structures) consists of constraints of the mathematical models of extremum problem in static formulation (22) and of Kuhn-Tucker conditions (23):

$$
\begin{gathered}
{[A] \mathbf{S}_{r}=\mathbf{0}, \quad[\Phi]\left(\mathbf{S}_{e}+\mathbf{S}_{r}\right) \leq \mathbf{S}_{0},} \\
\nabla\left(\mathbf{S}_{r}\right)+[\Phi]^{T} \lambda-[A]^{T} \mathbf{u}_{r}=\mathbf{0}, \\
\lambda \geq \mathbf{0}, \quad \lambda^{T}\left[\mathbf{S}_{0}-[\Phi]\left(\mathbf{S}_{e}+\mathbf{S}_{r}\right)\right]=0 .
\end{gathered}
$$

The solution of the set of relations (37) are the vectors $\mathbf{S}_{r}^{*}, \mathbf{u}_{r}^{*}, \lambda^{*}$. They completely agree with the solution of dual pair of mathematical programming problems (21)-(22), (28)-(29).

The residual displacements $\mathbf{u}_{r}$ and stresses $\mathbf{S}_{r}$ can be expressed in the form:

$$
\begin{gathered}
\mathbf{u}_{r}=[\bar{H}][\Phi]^{T} \lambda=[H] \lambda, \\
\mathbf{S}_{r}=[\bar{G}][\Phi]^{T} \lambda=[G] \lambda .
\end{gathered}
$$

Here:

$$
\begin{gathered}
{[\bar{H}]=\left([A][D]^{-1}[A]^{T}\right)^{-1}[A][D]^{-1}} \\
{[\bar{G}]=\left\{[D]^{-1}[A]^{T}\left([A][D]^{-1}[A]^{T}\right)^{-1}[A][D]^{-1}-[D]^{-1}\right\}}
\end{gathered}
$$

Then the relation system (37) reads:

$$
\begin{gathered}
-\mathbf{S}_{0}+[\Phi]\left(\mathbf{S}_{e}+[G] \lambda\right) \leq \mathbf{0}, \quad \lambda \geq \mathbf{0}, \\
\lambda^{T}\left[\mathbf{S}_{0}-[\Phi]\left(\mathbf{S}_{e}+[G] \lambda\right)\right]=0 .
\end{gathered}
$$

The elastic displacements $\mathbf{u}_{e}$ and the stresses $\mathbf{S}_{e}$ in the case of simultaneous action of distortion $q$ and external load $\mathbf{F}$ are expressed by [28]:

$$
\begin{aligned}
& \mathbf{u}_{e}=\mathbf{u}_{e f}+\mathbf{u}_{e q}=[\beta] \mathbf{F}+[\bar{H}] \mathbf{q}, \\
& \mathbf{S}_{e}=\mathbf{S}_{e f}+\mathbf{S}_{e q}=[\boldsymbol{\alpha}] \mathbf{F}+[\bar{G}] \mathbf{q} .
\end{aligned}
$$

Here $[\beta]$ is the influence matrix for elastic displacements.

Under the distortion $q$ and the external load $F$ mathematical model (21)-(22) reads:

$$
\begin{array}{r}
\text { find(21) subject to } \left.\begin{array}{r}
{[\mathrm{A}] \mathbf{S}_{\mathbf{r}}=\mathbf{0}} \\
{[\Phi]\left(\mathbf{S}_{\mathrm{ef}}+\mathbf{S}_{\mathrm{eq}}+\mathbf{S}_{\mathbf{r}}\right) \leq \mathbf{S}_{0}}
\end{array}\right\}
\end{array}
$$

Then the kinematic formulation of the problem (26)(27) reads:

$$
\text { find } \left.\begin{array}{rl}
\min & \left\{0.5 \cdot \mathbf{S}_{r}^{T}[D] \mathbf{S}_{r}+\lambda^{T}[\Phi] \mathbf{S}_{r}+\right. \\
+ & \left.\lambda^{T}\left[\mathbf{S}_{0}-[\Phi]\left(\mathbf{S}_{e f}+\mathbf{S}_{e q}+\mathbf{S}_{r}\right)\right]\right\}
\end{array}\right\}
$$

subject to (27).

For optimal solution of the problem (42) $\mathbf{S}_{r}^{*}, \mathbf{u}_{r}^{*}, \lambda^{*}$ the relation

$$
\lambda^{* T}\left[\mathbf{S}_{0}-[\Phi]\left(\mathbf{S}_{e f}+\mathbf{S}_{e q}+\mathbf{S}_{r}^{*}\right)\right]=0
$$

is valid. The relationship (43) contains the direct work of plastic strains

$$
D_{e}=\lambda^{* T}[\Phi]\left(\mathbf{S}_{e f}+\mathbf{S}_{e q}\right)=\lambda^{* T}[\Phi] \mathbf{S}_{e} .
$$

Multiplication product $D_{e q}=\lambda^{* T}[\Phi] \mathbf{S}_{e q}$ can be interpreted as a virtual work of stresses $\mathbf{S}_{e q}$ (when the plastic strains $\Theta_{p}^{*}=[\Phi]^{T} \lambda^{*}$ were caused by the stresses $\mathbf{S}_{e f}$ only). Prestressing is expressed via the vector $q$ in this case. On the other hand, the work $D_{e q}$, the product of the resultant external load $\mathbf{F}_{q}=[A][D]^{-1} \mathbf{q}$ can be interpreted as the virtual work of the force $F_{q}$ (following the Betti theorem) [23], [24]. 
3.5. An exceptional case of shakedown analysis problem

Description of the cyclic load by variation bounds $\mathbf{F}_{\text {inf }}, \mathbf{F}_{\text {sup }}\left(\mathbf{F}_{\text {inf }} \leq \mathbf{F}(t) \leq \mathbf{F}_{\text {sup }}\right)$ does not yield any information about the sequence in which different combinations of the loads can be realised. The combination of loads, leading to the shakedown state of the structure without unloading is to be determined [4], [19]. Then the static formulation of such problem reads :

find

$$
\min \quad 0.5 \cdot \mathbf{S}_{r}^{T}[D] \mathbf{S}_{r}=U^{*}
$$

subject to

$$
[A] \mathbf{S}_{r}=\mathbf{0},
$$

$[\Phi]\left(\mathbf{S}_{e j, \max }+\mathbf{S}_{r}\right) \leq \mathbf{S}_{0}, \quad[\Phi]\left(\mathbf{S}_{e j, \min }+\mathbf{S}_{r}\right) \leq \mathbf{S}_{0} \quad$ for all values $j \in J$.

The vectors $\mathbf{S}_{0}, \mathbf{S}_{e j, \max }, \mathbf{S}_{e j, \min }$ in problem (45) (46) are assumed to be prescribed. By solving the problem (45)-(46), the vector $S_{r}^{*}$ is determined.

The kinematic formulation of the problem reads:

find

$$
\begin{aligned}
& \min \left\{0.5 \cdot \mathbf{S}_{r}^{T}[D] \mathbf{S}_{r}+\sum_{j} \lambda_{j, \max }^{T}[\Phi] \mathbf{S}_{r}+\right. \\
& +\sum_{j} \lambda_{j, \min }^{T}[\Phi] \mathbf{S}_{r}+\sum_{j} \lambda_{j, \max }^{T}\left[\mathbf{S}_{0}-[\Phi]\left(\mathbf{S}_{e j, \max }+\mathbf{S}_{r}\right)\right]+ \\
& \left.+\sum_{j} \lambda_{j, \min }^{T}\left[\mathbf{S}_{0}-[\Phi]\left(\mathbf{S}_{e j, \min }+\mathbf{S}_{r}\right)\right]\right\}=\Pi^{*}
\end{aligned}
$$

subject to

$$
\begin{gathered}
{[D] \mathbf{S}_{r}+\sum_{j}[\Phi]^{T} \lambda_{j, \max }+\sum_{j}[\Phi]^{T} \lambda_{j, \min }-[A]^{T} \mathbf{u}_{r}=\mathbf{0}} \\
\lambda_{j, \max } \geq \mathbf{0}, \quad \lambda_{j, \min } \geq \mathbf{0}, j \in J
\end{gathered}
$$

The problem (47)-(48) corresponds to the minimum total potential energy principle. By solving the problem (47)-(48), the vectors $\mathbf{s}_{r}^{*}, \mathbf{u}_{r}^{*}, \lambda^{*}$

$$
\lambda^{*}=\sum_{j}\left(\lambda_{j, \max }^{*}+\lambda_{j, \min }^{*}\right) \text { and } D_{\min }=\lambda^{* T} \mathbf{S}_{0}
$$

are obtained. Via $D_{\min }$ the minimum value of energy dissipation, required to reach the state of shakedown is denoted. The optimal solution
$\mathbf{S}_{r}^{*}, \mathbf{u}_{r}^{*}, \lambda^{*}$ satisfies the conditions (14), (15). It is required to mark that $\mathbf{s}_{r}^{*}, \mathbf{u}_{r}^{*}, \lambda^{*}$, in general, depend on the loading history $F(t)$ and are not unique for the shakedown state.

Further the case, when the shakedown state is obtained under the unique vector of $\mathbf{S}_{r}(t)=\mathbf{S}_{r}^{*}$ for all histories of loading $F(t)$ is under consideration. This is valid for the moment prior to the cyclic plastic failure (when the safety factor of shakedown is approximate to 1) [20], [25], [26]:

find

$\max \mathbf{s}$

subject to

$$
[A] \mathbf{S}_{r}=\mathbf{0},
$$

$[\Phi]\left(\mathbf{S}_{e j, \max }+\overline{\mathbf{S}}_{r}\right) \leq \frac{1}{s} \mathbf{S}_{0}, \quad[\Phi]\left(\mathbf{S}_{e j, \min }+\overline{\mathbf{S}}_{r}\right) \leq \frac{1}{s} \mathbf{S}_{0}$

for all values $j \in J$.

The extremum elastic stresses $\mathbf{S}_{e j, \max }, \mathbf{S}_{e j, \min }$ are assumed to be known. By solving the problem (49)(50), the value $s \cdot \overline{\mathbf{S}}_{r}^{*}$ prior to the cyclic plastic failure is determined. The solution of the problem, dual to the problem (49)-(50), can be obtained by solving the compatibility equations for residual strains:

$$
\begin{gathered}
{\left[B_{\lambda}\right] \bar{\lambda}=\left[B_{r}\right] s \cdot \overline{\mathbf{S}}_{r}^{*}, \quad \bar{\lambda} \geq \mathbf{0},} \\
\bar{\lambda}^{T}\left[\mathbf{S}_{0}-[\Phi]\left(\mathbf{S}_{e}+s \cdot \overline{\mathbf{S}}_{r}^{*}\right)\right]=0
\end{gathered}
$$

In general, the vector $\mathbf{S}_{e}$ corresponds to the active yield conditions. The basis vector $\bar{\lambda}^{*}$ is the solution of the system (51). The degenerate case of the problem (51) is more closely considered in [23].

Return to consideration of the mathematical models (45)-(46), (47)-(48), when the yield conditions were written for every design cross-section. The dimensions of the aforementioned problems can be reduced, turning out the non-active yield conditions. The yield conditions new matrix $\left[\Phi^{*}\right]$ and the limit stress vector $\mathbf{S}_{0}^{*}$ due to this matrix are formed. For this purpose the optimal solution $\mathbf{S}_{r}^{*}$ of the problem (45)-(46) is used: 
$\max _{\mu, p}\left[\Phi_{i}\right]\left(\mathbf{S}_{e i, p}+\mathbf{S}_{n i}^{*}\right)=\left[\Phi_{i}^{*}\right]\left(\mathbf{S}_{e i}^{*}+\mathbf{S}_{n i}^{*}\right), \quad i \in I, p \in P$

The obtained vector $\mathbf{S}_{0}^{*}$ differs from the primary vector $S_{0}$ by the reduced dimensions. By using the matrix $\left[\Phi^{*}\right]$ and the vector $\mathbf{S}_{e}^{*}$, the problem

(46) can be transformed to:

find (45) subject to $[A] \mathbf{S}_{r}=\mathbf{0}$,

$$
\left[\Phi^{*}\right]\left(\mathbf{S}_{e}^{*}+\mathbf{S}_{r}\right) \leq \mathbf{S}_{0}^{*} .
$$

By analogy, the kinematic formulation (47)-(48) of the aforementioned problem is reduced, too. Then the plastic strains $\Theta_{p}^{*}$ can be obtained via the following expression: $\Theta_{p}^{*}=\left[\Phi^{*}\right]^{T} \lambda_{0}^{*}=[\Phi]^{T} \lambda^{*}$.

Dimensions of the vectors $S_{0}^{*}$ and $\lambda_{0}^{*}$ coincide. Finally, the energy equation (36) for $\mathbf{s}_{r}^{*}, \mathbf{u}_{r}^{*}, \lambda_{0}^{*}$ reads:

$$
D_{\min }=-\mathbf{S}_{r}^{* T}[D] \mathbf{S}_{r}^{*}+\lambda_{0}^{* T}\left[\Phi^{*}\right] \mathbf{S}_{e}^{*}
$$

The characteristic features of cyclic loading are considered in the cycle $\tau$. For the exceptional case of the shakedown analysis problem the irreversible work of external loads $W$ is expressed by:

$$
W(\tau)=\int_{0}^{\tau} \dot{\mathbf{u}}_{r}^{T}(t) \cdot \mathbf{F}(t) d t=\mathbf{u}_{r, \text { inf }}^{T} \cdot \mathbf{F}_{\text {inf }}+\mathbf{u}_{r, s u p}^{T} \cdot \mathbf{F}_{s u p} .
$$

Here $\mathbf{u}_{r, \text { inf }}, \mathbf{u}_{r, \text { sup }}$ are the vectors of lower and upper bounds of residual displacements $\mathbf{u}_{r}(t)$ $\left(\mathbf{u}_{r, \text { inf }} \leq \mathbf{u}_{r}(t) \leq \mathbf{u}_{r, \text { sup }}\right)$, respectively. It is known that

$$
\mathbf{u}_{r}^{*}=[\bar{H}] \Theta_{p}^{*}=[\bar{H}][\Phi]^{T} \lambda^{*}=[H] \lambda^{*} .
$$

By using the matrix $\left[\Phi^{*}\right]$ and the vector $\lambda_{0}^{*}$

$$
\mathbf{u}_{r}^{*}=[\bar{H}]\left[\Phi^{*}\right]^{T} \lambda_{0}^{*}
$$

In general, the vectors $\mathbf{u}_{r, \text { inf }}, \mathbf{u}_{r, \text { sup }}$ in the exceptional case of shakedown analysis problem can be obtained from the following expressions:

$$
\mathbf{u}_{r, \text { sup }}=\left[H_{\text {sup }}\right] \lambda^{*}, \quad \mathbf{u}_{r, \text { inf }}=\left[H_{\text {inf }}\right] \lambda^{*} .
$$

For the simple loading $\mathbf{F}=\mathbf{F}_{\text {inf }}=\mathbf{F}_{\text {sup }}$,

$$
\mathbf{u}_{r}=\mathbf{u}_{r, \text { inf }}+\mathbf{u}_{r, \text { sup }} \text { and } W=\mathbf{F}^{T} \mathbf{u}_{r} .
$$

If the mathematical models (45)-(46), (47)-(48) contain the extremum elastic stresses described by $\mathbf{S}_{e, \text { inf }} \leq \mathbf{S}_{e}(t) \leq \mathbf{S}_{e, \text { sup }}$, then for the cycle $\tau$

$$
D_{e}(\tau)=\int_{0}^{\tau} \mathbf{S}_{e}^{T}(t) \cdot \dot{\Theta}_{p}(t) d t=\mathbf{S}_{e, \text { inf }}^{T} \Theta_{p, \text { inf }}^{*}+\mathbf{S}_{e, \text { sup }}^{T} \Theta_{p, \text { sup }}^{*}
$$

Here $\mathbf{S}_{e, \text { sup }}=\left[\alpha_{\text {sup }}\right] \mathbf{F}_{\text {sup }}+\left[\alpha_{\text {inf }}\right] \mathbf{F}_{\text {inf }}$,

$$
\mathbf{S}_{e, \text { inf }}=\left[\alpha_{\text {inf }}\right] \mathbf{F}_{\text {sup }}+\left[\alpha_{\text {sup }}\right] \mathbf{F}_{\text {inf }} .
$$

\section{Step-by-step method in shakedown analysis problems}

\subsection{Mathematical models}

Usually the cyclic loading is accompanied by unloading of the structure. In this case for determining SSF of the structure one needs to consider the plastic deformation history. The mathematical models (21)-(22), (28)-(29) (or (45)(46), (47)-(48)) to determine SSF cannot be directly applied for the final values of external load $F$. However, aforementioned mathematical models can be applied, when analysing the incremental process of loading, i.e. for every step $\Delta \mathbf{F}_{v}$. Thus, the general methods can be used in respect of the different actions of external loads [19], [27] - [29].

For the $v$ step of the plastic deformation process the vector of total stresses $\mathbf{S}_{v}$ reads:

$$
\mathbf{S}_{v}=\mathbf{S}_{e f, v}+\mathbf{S}_{e q, v}+\Delta \mathbf{S}_{n} .
$$

Here $\mathbf{S}_{e q, v}=\sum_{k=1}^{v-1} \Delta \mathbf{S}_{r k}$ is the vector of residual stresses for the $v$-th step. In formula (57) $\Delta \mathbf{S}_{n}$ is the vector of increments of residual stresses for the $v$-th step (further the actual increments of residual stresses will be denoted as $\Delta \mathbf{S}_{n}^{*}$ ). Usually, for the beginning of the plastic deformation process the vector $\mathbf{S}_{e q}=\mathbf{0}$. The vector of elastic stresses increments is defined by $\Delta \mathbf{S}_{e f, v}=[\alpha] \Delta \mathbf{F}_{v}$, then the vector $\mathbf{S}_{e f, \nu}=\sum_{k=1}^{v} \Delta \mathbf{S}_{e f, \nu}$. Changing the increment $\Delta \mathbf{F}_{v}$, one can fix the unloading in the cross-sections 
(when required it is possible to regulate the duration of the step $v$ ). Fixing the beginning of the unloading phenomenon ensures a more exact determination of the actual $\Delta \mathbf{S}_{n}^{*}$.

The vector of the total displacements $\mathbf{u}_{v}$ in the $v$-th step reads:

$$
\mathbf{u}_{v}=\mathbf{u}_{e f, v}+\mathbf{u}_{e q, v}+\Delta \mathbf{u}_{w} .
$$

Here $\mathbf{u}_{e q, v}=\sum_{k=1}^{v-1} \Delta \mathbf{u}_{r k}$ is the vector of the residual displacements for $v$-th step. The value in the formula (58) $\Delta \mathbf{u}_{w}$ is the vector of increments of residual displacements for the $v$-th step. The vector of elastic displacement increments $\mathbf{u}_{e f, v}$ is obtained by $\mathbf{u}_{e f, v}=\sum_{k=1}^{v}[\beta] \Delta \mathbf{F}_{v}$.

Static formulation for step-by-step analysis of SSF for the increments of residual stresses $\Delta \mathbf{S}_{r}$ reads:

find

$$
\min 0,5 \Delta \mathbf{S}_{n}^{T}[D] \Delta \mathbf{S}_{n}=\Delta U_{v}^{*}
$$

subject to

$$
\begin{gathered}
{[A] \Delta \mathbf{S}_{n}=\mathbf{0},} \\
{[\Phi]\left(\mathbf{S}_{e f, v}+\mathbf{S}_{e q, v}+\Delta \mathbf{S}_{n}\right) \leq \mathbf{S}_{0} .}
\end{gathered}
$$

By solving the problem (59)-(60), the vector of actual increments of the residual stresses $\Delta \mathbf{S}_{n}^{*}$ and the increment of complementary energy $\Delta U_{v}^{*}$ are obtained. Now it is obvious that the aforementioned residual stresses $\mathbf{S}_{e q, v}$ is the incremental sum $\mathbf{S}_{e q, v}=\sum_{k=1}^{\nu-1} \Delta \mathbf{S}_{r k}^{*}$

The kinematic formulation for the step-by-step analysis of SSF for the increments of the residual displacements $\Delta \mathbf{u}_{n}$ and strains $\Delta \Theta_{r}$ reads:

find

$$
\begin{aligned}
& \min \left\{0.5 \cdot \Delta \mathbf{S}_{n}^{T}[D] \Delta \mathbf{S}_{n}+\Delta \lambda_{v}^{T}[\Phi] \Delta \mathbf{S}_{n}+\right. \\
& \left.+\Delta \lambda_{v}^{T}\left[\mathbf{S}_{0}-[\Phi]\left(\mathbf{S}_{e f, v}+\mathbf{S}_{e q, v}+\Delta \mathbf{S}_{w}\right)\right]\right\}=\Delta \Pi_{v}^{*}
\end{aligned}
$$

subject to

$$
[D] \Delta \mathbf{S}_{w}+[\Phi]^{T} \Delta \lambda_{v}-[A]^{T} \Delta \mathbf{u}_{r}=\mathbf{0}, \Delta \lambda_{v} \geq \mathbf{0} .
$$

By solving the problem (61)-(62), the vectors $\Delta \mathbf{S}_{n}^{*}$, $\Delta \mathbf{u}_{n}^{*}, \Delta \lambda_{v}^{*}$ are obtained. The objective function (61) of the problem (61)-(62) means the increment of the total potential energy $\Delta \Pi_{v}^{*}$.

According to the first duality theorem $\Delta \lambda_{v}^{* T}[\Phi] \Delta \mathbf{S}_{w}^{*}=-\Delta \mathbf{S}_{w}^{* T}[D] \Delta \mathbf{S}_{w}^{*} . \quad$ The actual increment of the residual stresses is $\Delta \mathbf{S}_{w}^{*}=[\bar{G}][\Phi]^{T} \Delta \lambda_{v}^{*}$. By using the formula (40), the vector $\mathbf{S}_{e q, v}=\sum_{k=1}^{v-1} \Delta \mathbf{S}_{r k}^{*}$ can be determined by

$$
\mathbf{S}_{e q, v}=[\bar{G}] \mathbf{q}_{v}=[\bar{G}][\Phi]^{T} \lambda_{\nu-1}^{*}=[G] \sum_{k=1}^{\nu-1} \Delta \lambda_{k}^{*}
$$

The compatibility equations (24)-(25) for the increments of the residual strains

$$
\begin{gathered}
\Delta \Theta_{r v}=[D] \Delta \mathbf{S}_{w}+\Delta \Theta_{p v}, \\
\Delta \Theta_{p v}=[\Phi]^{T} \Delta \lambda_{v}, \quad \Delta \lambda_{v} \geq \mathbf{0},
\end{gathered}
$$$$
\text { reads: } \quad\left[B_{\lambda}\right] \Delta \lambda_{v}=\left[B_{r}\right] \Delta \mathbf{S}_{w} \text {. }
$$

Then the analysis problem in kinematic formulation is as follows:

find

$$
\begin{aligned}
\min & \left\{0.5 \cdot \Delta \mathbf{S}_{w}^{T}[D] \Delta \mathbf{S}_{v}+\Delta \lambda_{v}^{T}[\Phi] \Delta \mathbf{S}_{w}+\right. \\
+ & \left.\Delta \lambda_{v}^{T}\left[\mathbf{S}_{0}-[\Phi]\left(\mathbf{S}_{e f, v}+\mathbf{S}_{e q, v}+\Delta \mathbf{S}_{w}\right)\right]\right\}
\end{aligned}
$$

subject to

$$
\left[B_{\lambda}\right] \Delta \lambda_{v}=\left[B_{r}\right] \Delta \mathbf{S}_{r}, \Delta \lambda_{v} \geq \mathbf{0} .
$$

The vectors $\Delta \lambda_{v}, \Delta \mathbf{S}_{n}$ are the unknown values in the problem (64)-(65).

For the vectors $\Delta \mathbf{S}_{n}^{*}, \quad \Delta \mathbf{u}_{n}^{*}, \Delta \lambda_{v}^{*}$ being already determined, the total residual stresses $\mathbf{S}_{n}^{*}$, displacements $\mathbf{u}_{n}^{*}$, plastic strains $\Theta_{p v}^{*}$ and residual strains $\Theta_{n}^{*}$ for the end of $v$-th step are expressed by:

$$
\begin{gathered}
\mathbf{s}_{n}^{*}=\mathbf{S}_{e q, v}+\Delta \mathbf{S}_{n}^{*} \\
\mathbf{u}_{n}^{*}=\mathbf{u}_{e q, v}+\Delta \mathbf{u}_{v}^{*} \\
\Theta_{p v}^{*}=\sum_{v} \Delta \Theta_{p v}^{*}=\sum_{v}[\Phi]^{T} \Delta \lambda_{v}^{*}=[\Phi]^{T} \sum_{v} \Delta \lambda_{v}^{*}=[\Phi]^{T} \lambda_{v}^{*} \\
\lambda_{v}^{*}=\sum_{v} \Delta \lambda_{v}^{*}
\end{gathered}
$$




$$
\Theta_{n v}^{*}=[D] \mathbf{s}_{n}^{*}+\Theta_{p v}^{*} .
$$

The above - presented formulae are valid as well as for the intermediate as for the final moments of the plastic deformation process.

\subsection{Energy interpretation of local complementarity conditions}

The local complementarity condition (condition for the $v$-th step) for the optimal solution of the problem (64)-(65) (or (61)-(62)) is valid:

$$
\begin{gathered}
\Delta \lambda_{v}^{* T}\left[\mathbf{S}_{0}-[\Phi]\left(\mathbf{S}_{e f, v}+\mathbf{S}_{e q, v}+\Delta \mathbf{S}_{w}^{*}\right)\right]=0, \\
\Delta \lambda_{v}^{* T} \geq \mathbf{0} .
\end{gathered}
$$

On the other hand, the condition (70) reads:

$$
\begin{aligned}
\Delta \lambda_{v}^{* T} \mathbf{S}_{0} & =\Delta \lambda_{v}^{* T}[\Phi] \Delta \mathbf{S}_{v}^{*}+\Delta \lambda_{v}^{* T}[\Phi] \mathbf{S}_{e q, v}+ \\
& +\Delta \lambda_{v}^{* T}[\Phi] \mathbf{S}_{e f, v} .
\end{aligned}
$$

The left item of the formula (71) means the increment of the total energy dissipation $\Delta D_{v}=\Delta \lambda_{v}^{* T} \mathbf{S}_{0}$. The first item on the right side of the equation (71) means the actual work of residual stresses $\Delta \mathbf{S}_{n}^{*}$ of the $v$-th step:

$$
\Delta D_{n}=\Delta \lambda_{v}^{* T}[\Phi] \Delta \mathbf{S}_{n}^{*} .
$$

The second item on the right side of the equation (71) means the virtual work of the residual stresses $\mathrm{S}_{e q, v}$ for the $v$-th step:

$$
\Delta D_{e q, v}=\Delta \lambda_{v}^{* T}[\Phi] \mathbf{S}_{e q, v} .
$$

The third item on the right side of the equation (71) means the direct work of plastic strains $\Delta \Theta_{p v}^{*}$ for the $v$-th step:

$$
\Delta D_{e v}=\Delta \lambda_{\nu}^{* T}[\Phi] \mathbf{s}_{e f, v}^{*} .
$$

For the complete process of plastic deformation, consisting from $v$ steps, the equation

$$
\sum_{v} \Delta \lambda_{v}^{* T}\left[\mathbf{S}_{0}-[\Phi]\left(\mathbf{S}_{e f, v}+\mathbf{S}_{e q, v}+\Delta \mathbf{S}_{r}^{*}\right)\right]=0
$$

is valid. Finally, we have:

$$
\sum_{v} \Delta D_{v}=\sum_{v} \Delta D_{n}+\sum_{v} \Delta D_{e q, v}+\sum_{v} \Delta D_{e v}
$$

The formula (76) allows to determine the total energy dissipation:

$$
D_{v}=D_{r v}+D_{e q, v}+D_{e v},
$$

which is analogous to the formula (20).

\subsection{On relationship of the local and global complementarity conditions}

Now we are in the position to compare the solution results of the extremum analysis problems for holonomic structures (21)-(22), (28)-(29) (or (45)-(46), (47)-(48)) with those of the step-by-step extremum analysis problems (59)-(60), (61)-(62). For the holonomic structures $\mathbf{S}_{n}^{*}=\mathbf{S}_{r}^{*}$ (here $\mathbf{S}_{r}^{*}$ is the optimal solution of the problems (21)-(22), (45)(46)). Then the complementarity conditions - the local (for all $v$ steps)

$$
\Delta \lambda_{v}^{* T}\left[\mathbf{S}_{0}-[\Phi]\left(\mathbf{S}_{e f, v}+\mathbf{S}_{e q, v}+\Delta \mathbf{S}_{r v}^{*}\right)\right]=0,
$$

as well as the global

$$
\lambda_{\nu}^{* T}\left[\mathbf{S}_{0}-[\Phi]\left(\mathbf{S}_{e}^{*}+\mathbf{S}_{v}^{*}\right)\right]=0
$$

are valid. Here

$$
\lambda_{v}^{*}=\sum_{v} \Delta \lambda_{v}^{*}, \quad \mathbf{S}_{e} \equiv[\alpha] \mathbf{F}, \mathbf{S}_{n}^{*}=\mathbf{S}_{e q, v}+\Delta \mathbf{S}_{n}^{*}
$$

When the conditions (78), (79) are satisfied, the numerical value $D_{v}$ (the numerical result according to (77)) coincides with the value $D=\lambda^{* T} \mathrm{~S}_{0}$ (the numerical result according to (35)). By the expression (36), it can be proved that

$$
D=-\mathbf{S}_{r}^{* T}[D] \mathbf{S}_{r}^{*}+\mathbf{S}_{e}^{* T}[\Phi]^{T} \lambda^{*}=\mathbf{S}_{r}^{* T} \Theta_{p}^{*}+\mathbf{S}_{e}^{* T} \Theta_{p}^{*}
$$

Let us consider the two-steps analysis of the plastic deformation. In this case $v=2$ and

$$
\mathbf{S}_{r}^{*}=\Delta \mathbf{S}_{r 1}^{*}+\Delta \mathbf{S}_{r 2}^{*}, \quad \mathbf{S}_{e}=\Delta \mathbf{S}_{e 1}+\Delta \mathbf{S}_{e 2},
$$

$\Theta_{p}^{*}=\Delta \Theta_{p 1}^{*}+\Delta \Theta_{p 2}^{*}$ (for convenience, further the indices ${ }^{*}$ for $\Delta \mathbf{S}_{e 1}, \Delta \mathbf{S}_{e 2}$ are missed). Then the energy dissipation is calculated as:

$$
\begin{aligned}
D & =\Delta D_{1}+\Delta D_{2}=\left(\Delta \mathbf{S}_{r 1}^{* T}+\Delta \mathbf{S}_{r 2}^{* T}\right)\left(\Delta \Theta_{p 1}^{*}+\Delta \Theta_{p 2}^{*}\right)+ \\
& +\left(\Delta \mathbf{S}_{e 1}^{T}+\Delta \mathbf{S}_{e 2}^{T}\right)\left(\Delta \Theta_{p 1}^{*}+\Delta \Theta_{p 2}^{*}\right)= \\
= & \Delta \mathbf{S}_{r 1}^{* T} \Delta \Theta_{p 1}^{*}+\left(\Delta \mathbf{S}_{e 2}^{T}+\Delta \mathbf{S}_{r 2}^{* T}\right) \Delta \Theta_{p 1}^{*}+\Delta \mathbf{S}_{e 1}^{T} \Delta \Theta_{p 1}^{*}+
\end{aligned}
$$


$+\Delta \mathbf{S}_{r 2}^{* T} \Delta \Theta_{p 2}^{*}+\Delta \mathbf{S}_{r 1}^{* T} \Delta \Theta_{p 2}^{*}+\left(\Delta \mathbf{S}_{e 1}^{T}+\Delta \mathbf{S}_{e 2}^{T}\right) \Delta \Theta_{p 2}^{*}$.

For the every step of the plastic deformation the energy dissipation $\Delta D_{v}$ is calculated by:

$$
\begin{aligned}
& \Delta D_{1}=\Delta \lambda_{1}^{* T} \mathbf{S}_{0}=\Delta \mathbf{S}_{r 1}^{* T} \Delta \Theta_{p 1}^{*}+ \\
& +\left(\Delta \mathbf{S}_{e 2}^{T}+\Delta \mathbf{S}_{r 2}^{* T}\right) \Delta \Theta_{p 1}^{*}+\Delta \mathbf{S}_{e 1}^{T} \Delta \Theta_{p 1}^{*}, \\
& \Delta D_{2}=\Delta \lambda_{2}^{* T} \mathbf{S}_{0}=\Delta \mathbf{S}_{r 2}^{* T} \Delta \Theta_{p 2}^{*}+ \\
& +\Delta \mathbf{S}_{r 1}^{* T} \Delta \Theta_{p 2}^{*}+\left(\Delta \mathbf{S}_{e 1}^{T}+\Delta \mathbf{S}_{e 2}^{T}\right) \Delta \Theta_{p 2}^{*} .
\end{aligned}
$$

When the unloading does not appear, the scalar multiplication product $\left(\Delta \mathbf{S}_{e 2}^{T}+\Delta \mathbf{S}_{r 2}^{* T}\right) \Delta \Theta_{p 1}^{*}$ in the formula (80) is equal to zero (Fig. 1.), i.e.:

$$
\left(\Delta \mathbf{S}_{e 2}^{T}+\Delta \mathbf{S}_{r 2}^{* T}\right) \Delta \Theta_{p 1}^{*}=0
$$

Finally, we conclude that the expressions (80), (81) have the meaning of the local complementarity conditions (71) for $v=1,2$.

Further we consider more detailed the unloading phenomenon of the structure, when the global complementarity conditions in the mathematical models (45)-(46), (47)-(48) are not satisfied. To avoid it, the vector of fictitious limit stresses $\widetilde{\mathrm{S}}_{0}$ is introduced to satisfy the global complementary conditions as well. Then the mathematical models (21)-(22), (28)-(29) (or (45)-(46), (47)-(48)) to determine the SSF can be directly applied to the final

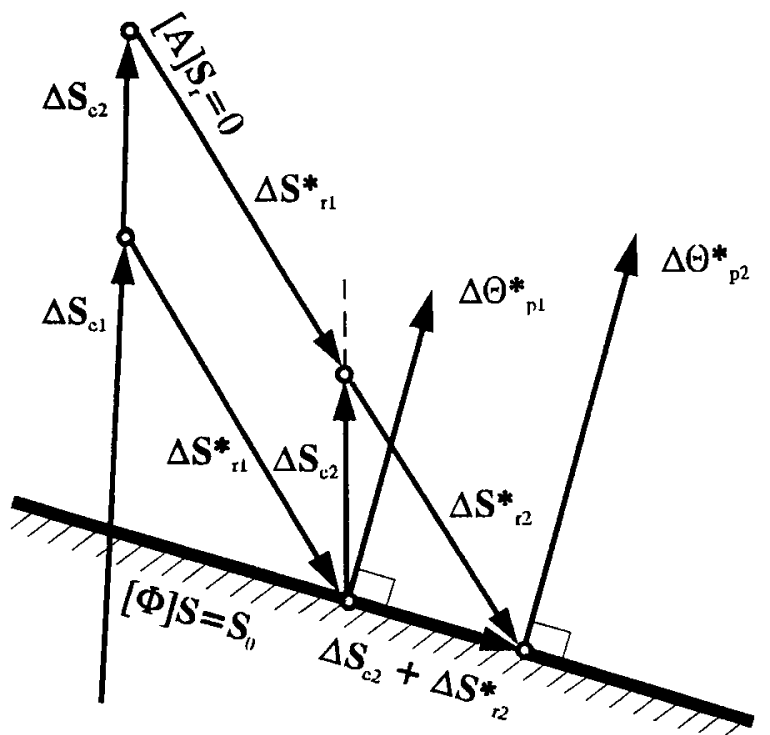

Fig. 1. On the determination of energy dissipation for holonomic structures values of $\mathbf{F}$. The optimal solution $\mathbf{S}_{n}^{*}$ of the problem (59)-(60) is applied to determine the vector $\widetilde{\mathbf{S}}_{0}$. The components of the vector $\widetilde{\mathrm{S}}_{0}$ in cross-sections, where the plastic strains $\Theta_{p v}^{*}$ are not equal to zero, are calculated according to the formula [30], [31]:

$$
\widetilde{\mathbf{S}}_{0 i}=\underset{\mu, p}{\max }\left[\Phi_{i}\right]\left(\mathbf{S}_{e i, p}+\mathbf{S}_{r v, i}^{*}\right), \quad i \in I, p \in P .
$$

Here $\mathbf{S}_{n}^{*}=\mathbf{S}_{e q, v}+\Delta \mathbf{S}_{v}^{*}$ (Fig. 2). The components of the vector $\widetilde{\mathbf{S}}_{0}$ do not change for the cross-sections where $\Theta_{p v}^{*}=0$. Then the static formulation of the extremum analysis problem reads [30] - [33]:

find

$$
\min \quad 0.5 \cdot \widetilde{\mathbf{S}}_{r}^{T}[D] \widetilde{\mathbf{S}}_{r}=\widetilde{U}^{*}
$$

subject to:

$$
[A] \widetilde{\mathbf{S}}_{r}=\mathbf{0}, \quad[\Phi]\left(\mathbf{S}_{e}^{*}+\widetilde{\mathbf{S}}_{r}\right) \leq \widetilde{\mathbf{S}}_{0} .
$$

The optimal solution of the problem (84)-(85), $\widetilde{\mathrm{s}}_{r}^{*}$ completely coincides with the solution of the step-by-

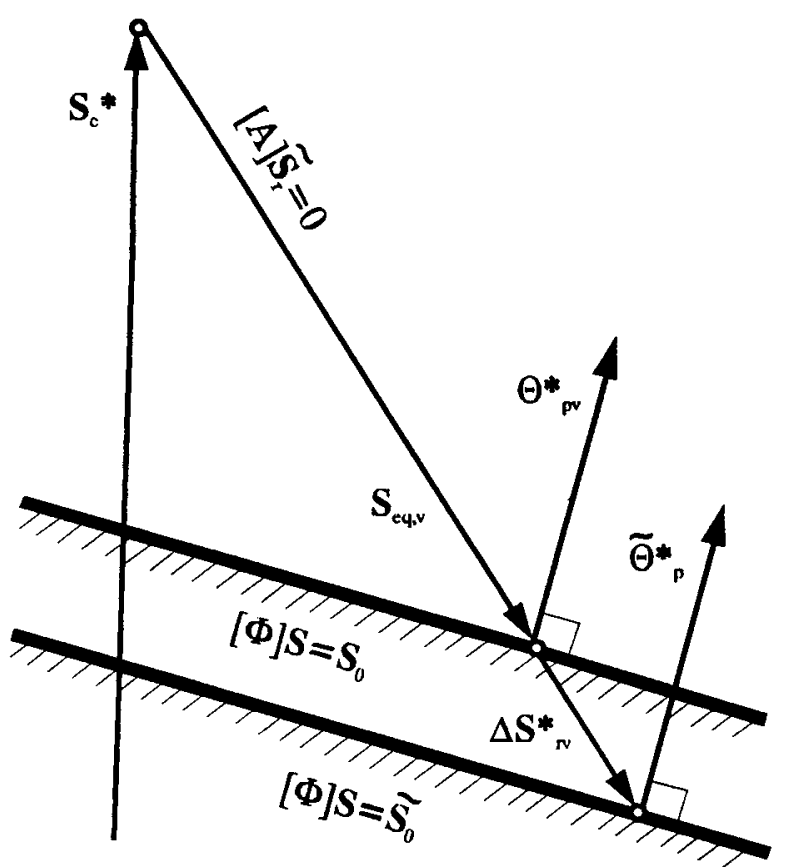

Fig. 2. On the relationship between the local and the global complementarity conditions

step problem (59)-(60), $\quad \mathbf{S}_{n}^{*}=\mathbf{S}_{e q, v}+\Delta \mathbf{S}_{n}^{*}$. The active yield conditions are predetermined by the vector $\widetilde{\mathbf{S}}_{0}$. The kinematic formulation of the analysis problem reads: 
find

$$
\begin{aligned}
& \max \left\{-0.5 \cdot \widetilde{\mathbf{S}}_{r}^{T}[D] \widetilde{\mathbf{S}}_{r}-\tilde{\lambda}^{T}[\Phi] \widetilde{\mathbf{S}}_{r}-\right. \\
& \left.-\tilde{\lambda}^{T}\left[\widetilde{\mathbf{S}}_{0}-[\Phi]\left(\mathbf{S}_{e}^{*}+\widetilde{\mathbf{S}}_{r}\right)\right]\right\}=\widetilde{\Pi}^{*}
\end{aligned}
$$

subject to

$$
[D] \widetilde{\mathbf{S}}_{r}+[\Phi]^{T} \tilde{\lambda}-[A]^{T} \tilde{\mathbf{u}}_{r}=\mathbf{0}, \quad \tilde{\lambda} \geq \mathbf{0} .
$$

By solving the problem (86)-(87), the vectors $\widetilde{\mathbf{S}}_{r}^{*}, \tilde{\lambda}^{*}, \widetilde{\mathbf{u}}_{r}^{*}$ are obtained. Thus the global complementarity conditions

$$
\tilde{\lambda}^{* T}\left[\widetilde{\mathbf{S}}_{0}-[\Phi]\left(\mathbf{S}_{e}^{*}+\widetilde{\mathbf{S}}_{r}^{*}\right)\right]=0, \tilde{\lambda}^{*} \geq \mathbf{0}
$$

are satisfied as well. Now, the energy dissipation $\widetilde{D}$ can be calculated by the formula

$$
\widetilde{D}=-\widetilde{\mathbf{S}}_{r}^{* T}[D] \widetilde{\mathbf{S}}_{r}^{*}+\mathbf{S}_{e}^{* T}[\Phi]^{T} \widetilde{\lambda}^{*}=\widetilde{\mathbf{S}}_{r}^{* T} \widetilde{\Theta}_{p}^{*}+\mathbf{S}_{e}^{* T} \widetilde{\Theta}_{p}^{*},
$$

when the vectors $\widetilde{\mathbf{S}}_{0}, \widetilde{\mathbf{S}}_{r}^{*}, \tilde{\lambda}^{*}$ (or the vector of plastic strains $\left.\tilde{\Theta}_{p}^{*}\right)$ are the already known values.

They completely coincide with those obtained by using the step-by-step problems, $\widetilde{\mathbf{S}}_{v v}^{*}, \tilde{\lambda}_{v}^{*}$. Thus the energy dissipation $\widetilde{D}$ is calculated by analogy with the formula (36). The actual value of the energy dissipation $D_{v}$ is determined by the formula

$$
D_{\mathrm{v}}=\widetilde{D}+\left(\mathbf{S}_{r}^{* T}-\widetilde{\mathbf{S}}_{r}^{* T}\right) \widetilde{\Theta}_{p}^{*}=\widetilde{D}+\tilde{\lambda}^{* T} \Delta \mathbf{S}_{0}
$$

Here $\Delta \mathbf{S}_{0}=\mathbf{S}_{0}-\widetilde{\mathbf{S}}_{0}$. The conclusions of the Betti theorem were applied to derive the relationship (90).

\section{Conclusions}

The residual displacements are related to the history of loading. The energy bounds of the possible states of shakedown are usually included in the constraints of the mathematical models of problems for the displacement estimation. The maximum value of the energy dissipation is within these bounds. The reliability of the results, obtained by solving the mathematical optimization problems for determining the variation limits of residual displacements essentialy depends on the accuracy of the maximum value of the energy dissipation. The minimum complementary energy principle of a fictitious structure obeying the holonomic law permits the upper bound of energy dissipation to be defined more accurately (it is ensured by a special energetic interpretation of the local and global complementarity conditions).

\section{References}

1. АЧирас. Методы линейного программирования при расчете упруго-пластических систем. Л.: Стройиздат, 1969. 199 c. (in Russian).

2. АЧирас. Теория оптимизации в предельном анализе твердого деформируемого тела. В.: Минтис, 1971. 124 c. (in Russian).

3. А.Чирас, А.Боркаускас, Р.Каркаускас. Теория и методы оптимизации упруго-пластических систем. Л.: Стройиздат, 1974. 280 c. (in Russian).

4. A.Cyras. Mathematical models for the analysis and optimization of elastoplastic structures. Chichester: Ellis Horwood Limited, 1983. 121 p.

5. G.Maier. Quadratic programming and theory of elastic-plastic structures // Meccanica, 3, 1968, p. 265273.

6. M.Z.Cohn, S.K.Gosh and S.R.Parimi. Unified approach to theory of plastic structures // J. Engrg. Mech. Div. 98, 1972, p. 1133-1158.

7. D.A.Gokhfeld, O.F.Cherniavsky. Limit analysis of structures at Thermal Cycling. Sijthoff and Noordhoff , 1980. 263 p.

8. J.A.König. Shakedown of Elastic-Plastic Structures. Warsawa: PWN, 1987. 214 p.

9. А.Чихас. Алгоритм расчета изгибаемой стержневой упруго-пластической системы с учетом реатной формы сечения // Литовский механический сборник, 16, 1976, c. 104-113. (in Russian).

10. A.R.S.Ponter. An upper bound to the small displacements of elastic perfectly plastic structures // J. Appl. Mech., 39, 1972, p. 959-963.

11. E.Vitiello. Upper bounds to plastic strains in shakedown of structures subjected to cyclic loads // Meccanica, 7, 1972, p. 205-213.

12. M.Capurso. A displacement bounding principle in shakedown of structures subjected to cyclic loads // Int. J. Solids Struct., 10, 1974, p. 77-92.

13. C.Polizzotto. On the Conditions to Prevent Plastic Shakedown of Structures: Part I. Theory // J. Appl. Mech, 60, 1993, p. 15-19.

14. F.Giambanco and L.Palizzolo. Bounds on plastic deformations of trusses. // Int. J. Solids Structures, 31, 6, 1994, p. 785-795.

15. L.Corradi and A.Zavellani. A linear programming approach to shakedown analysis structures // Comp. Meths. Appl. Mech. Eng., 3, 1974, p. 37-53.

16. St.Dorosz. An improved bound to maximum deflections of elastic-plastic structures at shakedown // J. Struct. Mech., 6, 1978, p. 267-287.

17. J.Atkočiūnas, A.Borkowski and J.A.König. Improved bounds for displacements at shakedown // Comput. Meth. appl. Mech. Engng ., 28, 1981, p. 365-376. 
18. A.Cyras and J.Atkočiūnas. Mathematical model for the analysis of elastic-plastic structures under repeatedvariable loading // Mech. Res. comm., 11, 1984, p. 353360.

19. Ю.Ю.Аткочюнас. Расчет упругопластических систем при повторных нагружениях. Вильнюс: Изд-во науки и энциклопедий, 1994. 148 c. (in Russian).

20. W.T.Koiter. General theorems for elastic-plastic solids // Progress in Solid Mechanics. Amsterdam: NorthHolland, 1960, p. 165-221.

21. A.König, M.Kleiber. On a New Method of Shakedown Analysis // Bulletin de l'Academie Polonaise des Sciences. Série des sciences techniques. Vol. XXVI, Nr.4, 1978, p. 167-171.

22. Mokhtar S.Bazaraa, C.M.Shetty. Nonlinear Programming Theory and Algorithms. New York, Chichester, Brisbane, Toronto: John Wiley, 1979. $283 \mathrm{p}$.

23. Ю.Ю.Аткочюнас. Условия Куна-Таккера в задачах приспособляемости // Statyba Nr. 1(5), 1996, V.: Technika, p. 14 -28 (in Russian).

24. Ю.Ю.Аткочюнас. Дисторсия в строительной мехаHuke // Statyba Nr. 1(1), 1995, V.: Technika, p. 3 - 24 (in Russian).

25. J.Atkočiūnas. New Approach to the Koiter's Inequality for shakedown // Mechanics Research Communications, 20, Nr.4, 1993, p. 301-308.

26. J.Atkočiūnas. Energetische Grenzen des Einspielzustandes elastoplastischer Konstruktionen // Wiss. Z. Hochsch. Archit. Bauwes, 41, 6/7, Weimar: 1995, p. 183 - 185 (in Germany).

27. A.Borkowski. Analysis of Skeletal Structural Systems in the Elastic and Elastic-Plastic Ranges. Warszawa: PWN - Elsevier, 1988. 200 p.

28. П.В.Алявдин. Анализ несущей способности и оптимальное проектирование упругопластических конструкщий. Минск: Рукопись деп. в ВНИИНТПИ 14 октября 1990, Nr. 10856. 436 c. (in Russian)

29. R.Karkauskas, V.Skaržauskas, J.Atkoðiūnas. Neholonominès elgsenos konstrukcijy analizè // Modern building materials, structures and techniques. Proceedings of the IV International Conference, Vilnius, May 10-13, 1995. Vol. 3. Vilnius: Technika, 1995, p. 266-270 (in Lithuanian).

30. J.Atkočiūnas. State analysis of discrete structures at shakedown under repeated loadings // Lithuanian J. of Computational Mechanics, 33, 1994, V.: Technika, p. 46-55.

31. J.Atkočiūnas, ANorkus. Method of fictitious system for evaluation of frames shakedown displacements // Computers and Structures, 50, Nr.4, 1994, p. 563-567.

32. J.Atkočiūnas. Holonomic analysis for displacements at shakedown via quadratic programming // Mechanika, 2, 1995, Kaunas: Technologija, p. 18 - 23.

33. J.Atkočiūnas. Quadratic programming for degenerate shakedown problems of bar structures // Mechanics Research Communications, 23, Nr. 2, 1996, p. 195-203.
ENERGETINẼ GRIEŽTUMO SALYGU INTERPRETACUJA PRISITAIKYMO UŽDAVINIUOSE

\section{J.Atkočiūnas}

\section{S a n tra u a}

Straipsnis skirtas matematinio programavimo metody taikymui prisitaikomumo teorijoje. Stipréjant kompiuterinei technikai, atsiranda vis nauju statybinès mechanikos metody skaičiuoti tampriujų-plastinių konstrukciju iłtempimų ir deformacijų būvius. Viena iš naujausių krypčiu žinomy fiziniy ir geometriniu duomeny konstrukcijos analizès uždavinių formulavimas, panaudojant matematinio programavimo teoriją. Ypač perspektyvu, jei analizès uždaviniu matematiniai modeliai sudaromi kieto deformuojamo kūno mechanikos ekstreminių energetinių principu pagrindu. Tuo atveju matematinio programavimo teorija padeda formuluoti sudètingu plastiškumo teorijos uždaviniu matematinius modelius ir juos išspręsti.

Taikant matematinị programavimą, viena iš pagrindinių problemy yra korektiškas jeinančių $i$ uždavinio dualius matematinius modelius sąlygu-apribojimų mechanistinis ir energetinis interpretavimas. Ta prasme sudetingiausia atsižvelgti $\mathfrak{i}$ matematinio programavimo teorijoje žinomas griežtumo sąlygas (jos yra kombinatorinès). Sprendžiant ekstreminius disipatyvinių sistemy analizès uždavinius su galutinèmis išoriniy poveikių reikšmèmis, minètomis griežtumo sąlygomis neįmanoma tiesiogiai fiksuoti pjūviu nusikrovimo. Prarandama galimybè atsižvelgti $\mathfrak{i}$ plastinio tekèjimo režimus, pasibaigiančius anksčiau, negu pasiektos galutinès išorinių poveikiu reikšmès. Tokie dalykai dažni, kai apkrova yra kartotine kintama.

Siūlomas būdas skaičiuoti energijos disipacijos reikšmei, kuri reikalinga konstrukcijos deformacijy būvio analizès uždavinių sprendimui. Būdas pagristas globalinèmis ir lokalinèmis griežtumo sąlygomis. Tuo tikslu išnagrinèti holonominès elgsenos konstrukcijy ekstreminiy uždavinių matematiniai modeliai, dualumo teoremy bei globalinių griežtumo sąlygu energetinè interpretacija. Holonominès konstrukciju elgsenos rèmuose suformuluoti ir atskirojo prisitaikymo būvio analizès uždavinio matematiniai modeliai, kai takumo sq̨lygose panaudojamos pseudotamprios ekstreminès įrąžos. Sprendžiant ṣ̌ uždavini apskaičiuojama minimali energijos, išsklaidomos siekiant prisitaikymo būvio, reikšmé. Ivedant fiktyvias ribines ịrąžas, gaunama formulè skaičiuoti nusikraunančios sistemos energijos disipacijos reikšmei, panaudojant atskirojo prisitaikymo būvio analizès uždavinio sprendimo rezultatus.

Juozas ATKOČIŨNAS. Doctor Habil, Associate Professor. Department of Structural Mechanics. Vilnius Gediminas Technical University (VGTU), 11 Saulètekio Ave, LT2040 Vilnius, Lithuania. E-mail: Juozas.Atkočiūnas @st.vtu.lt

Civil engineer, 1967. Dr Eng (structural mechanics), 1973. Dr Habil (mechanics), 1996. Research visits: Institute of Mechanics of Armenian Academy of Sciences, Warsaw Politechnical Institute, Moscow Civil Engineering Institute. Research interests: structural and computational mechanics, applied mathematical programming, analysis and optimization of dissipative structures under repeatedvariable loading. 